\title{
Incarceration of a Y-shaped fish bone in the upper thoracic oesophagus
}

\author{
Ming-Pin Lin, ${ }^{1}$ Yen-Li Chen, ${ }^{2}$ Wen-Sheng Tzeng ${ }^{1}$
}

${ }^{1}$ Department of Radiology, Chi-Mei Foundation Medical Center, Tainan, Taiwan ${ }^{2}$ Department of Medical Technology, Chen Shiu University, Kaohsiung, Taiwan

\section{Correspondence to} Dr Ming-Pin Lin, linmikea@yahoo.com.tw

Accepted 13 November 2014

\section{DESCRIPTION}

A 56-year-old man presented with severe chest pain with a foreign-body sensation and discomfort in his throat $2 \mathrm{~h}$ after having swallowed a fish bone. On arrival at the emergency department, his vital signs were stable. The level of $\mathrm{C}$ reactive protein was $7.9 \mathrm{mg} / \mathrm{dL}$ (normal range $<6$ ). Intense pain was noted when the patient swallowed during the physical examination. CT of the chest revealed a Y-shaped fish bone caught in the upper thoracic oesophagus (figure 1A, B). Oesophageal endoscopy confirmed the diagnosis, with subsequent removal of the incarcerated Y-shaped fish bone. CT scan is of great value in the diagnosis of complications of an incompletely swallowed fish bone. Complications may include oesophageal perforation, mediastinitis, mediastinal abscess or migration of a foreign body outside of the oesophagus into the subcutaneous tissue. Mediastinitis is a surgical emergency with a high mortality rate. ${ }^{1}$ CT is an important diagnostic modality for use by emergency physicians in the detection of an incarcerated Y-shaped fish bone in patients who need emergency oesophagoscopy or neck exploration.

\section{Learning points}

- Recognise the CT features in diagnosing complications of a trapped Y-shaped fish bone.

- Recognising the CT's precise evaluation of length, direction and surrounding anatomic relationships enables the surgeon to tailor a surgical approach.

Contributors M-PL wrote the article, W-ST collated data and $\mathrm{Y}-\mathrm{LC}$ revised the manuscript.

Competing interests None.

Patient consent Obtained.

Provenance and peer review Not commissioned; externally peer reviewed.

\section{REFERENCE}

1 Shihada R, Goldsher M, Sbait S, et al. Three-dimensional computed tomography for detection and management of ingested foreign bodies. Ear Nose Throat J 2009;88:910-11.
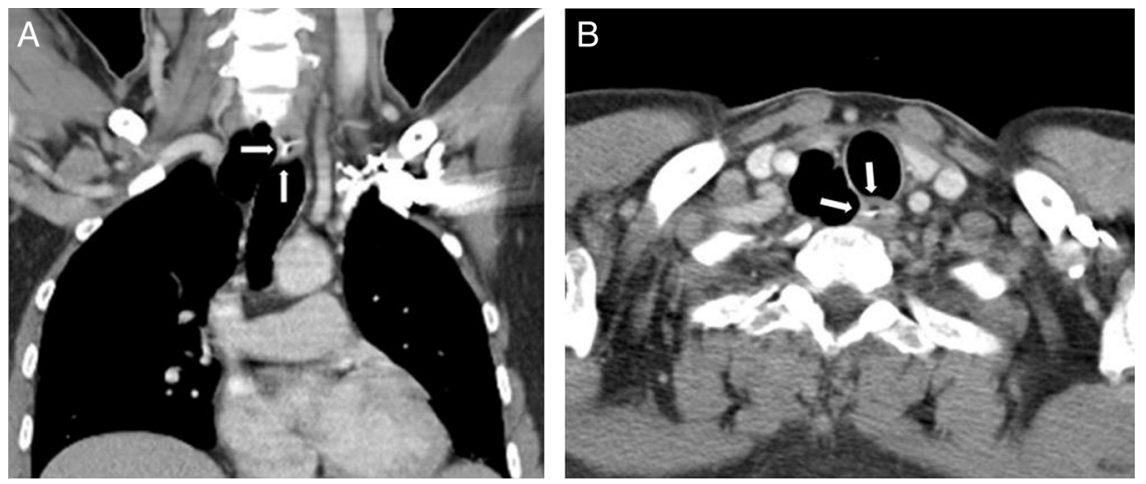

Figure $1 \mathrm{CT}$ of the chest revealed a Y shaped fish bone caught in the upper thoracic oesophagus. (A) coronal section, (B) axial section.

Copyright 2014 BMJ Publishing Group. All rights reserved. For permission to reuse any of this content visit http://group.bmj.com/group/rights-licensing/permissions.

BMJ Case Report Fellows may re-use this article for personal use and teaching without any further permission.

Become a Fellow of BMJ Case Reports today and you can:

- Submit as many cases as you like

- Enjoy fast sympathetic peer review and rapid publication of accepted articles

- Access all the published articles

- Re-use any of the published material for personal use and teaching without further permission

For information on Institutional Fellowships contact consortiasales@bmjgroup.com

Visit casereports.bmj.com for more articles like this and to become a Fellow 